\title{
Design-entrepreneurship in the post-recession economy: Parsons ELab, a Design School Incubator
}

\author{
Fry, Aaron; Alexander, Rhea; Ladhib, Samar
}

Abstract:

The "great recession" of 2008-09 in the U.S. was a watershed moment in the development of business practices that hold promise in driving the creation of a new generation of American companies and re-invigorating established businesses. These are i. the emergence of the sharing economy, ii. technological interconnectedness, iii. adoption of purpose-driven or cause-related value proposition(s) and iv. adaptability in the face of limited resources. This paper discusses the rise of design in the post-recession U.S. business landscape. We define attributes that designers share with entrepreneurs including adaptability, initiative, risk

\section{Cuadernos del Centro de Estudios de Diseño y Comunicación Nº 64}

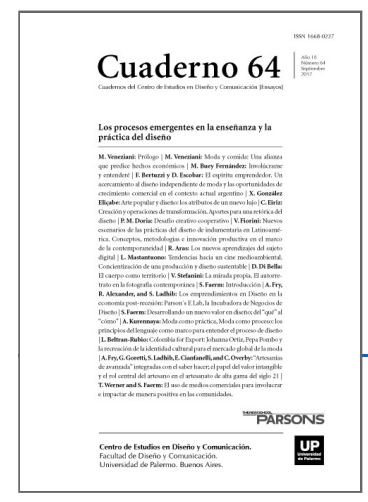

ISSN: 1668-0227

Los procesos

emergentes en la

enseñanza y la

práctica del diseño

Año XVIII, Septiembre 2017, Buenos Aires, Argentina | 326 páginas

descargar PDF

ver índice de la publicación

Ver todos los libros de la publicación

compartir en Facebook

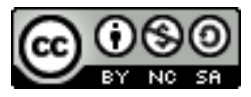

Esta obra está bajo una Licencia Creative Commons Atribución-NoComercialCompartirlgual 4.0 Internacional and failure-tolerance, ability to think-

and-work across disciplines, creativity and a problem-solving mindset. We describe these new roles and ways of working and discuss how they might be combined with intellectual capacities and resources available in higher education. Specifically, we present Parsons' Entrepreneurs Lab (ELab): a business incubator-design school hybrid that seeks to replicate the dynamic learning atmosphere of the post-recession American business landscape through a design-driven/socially-engaged networked model that addresses all four of the key dynamics driving start-up businesses in the post-recession environment.

Keywords:

post-recession business - academic design incubator - design-entrepreneur - sharing economy - lean strategy networked economy.

$\left({ }^{*}\right)$ Associate Professor of Design Strategies at Parsons School of Design (Associate Chair, Foundation, 20052008, Associate Director, Strategic Design and Management, 2016). Aaron is an artist, designer and educator with twenty years' full-time experience in the design education field, having previously taught full-time at three 
universities, two in his native country of New Zealand and prior to Parsons at Massachusetts College of Art and Design in Boston, Massachusetts between 1999 and 2005.

(*2) Assistant Professor and Co-director of the MS in Strategic Design \& Management Program at the School of Design Strategies (SDS). She teaches undergraduate and graduate courses in marketing, portfolio design, integrative studio, management and strategic design. Her research interests include the convergence of innovation, entrepreneurship, product design and sustainable business models. Currently she is involved in projects focusing on the impact design thinking has on entrepreneurship, technology and the new economy will have on academia and traditional business models, the relationship between startup culture and resilience thinking and the fusion of design thinking with business rationale.

(*3) Samar is a senior experience strategist at Wolff Olins with an extensive background in healthcare and pharmaceuticals. She is also an alumni of Parsons The School of Design where she was the operations and research lead at Parsons Entrepreneurial Lab. Samar has always been very involved in the innovation space . Very early on, she reinvented the chemotherapy drug preparation process as part her doctorate work and launched an in house dermatological line in Tunisia. Samar continues to follow her passion for innovation in New York City by creating powerful experiences that empower brands.

Introduction. America's post-recession business landscape

The authors identify the U.S. "great recession" of 2008-09 as a watershed event that marked a before, and an after, in regard to the operation of start-up firms in the United States. While certain trends existed -in nascent form- prior to 2008 , the recession and attendant shocks to the financial system created a scarcity of credit, anxiety about the future of the capitalist system, and much soul-searching about the broader purpose of business and economies amongst America's young people; a disproportionately-affected sector. If the recession catalyzed shifts in the ways that large companies viewed and conducted business, then the start-up firms created between 2008 and the present have tended to view these altered conditions as normative: building them into their business plans from inception. In the first section, we describe four defining shifts of the post-recession U.S. business landscape: i. the emergence of the sharing economy, ii. technological interconnectedness, iii. adoption of a purpose-driven, or cause-related, value proposition, and iv. adaptability in the face of limited resources. We then define who this post-recession designer-entrepreneur is, describing a "design-mindset" in which obstacles are viewed as parameters (which one designs for, and with). We describe how this mode of thinking has suffused U.S. startup culture in the intervening seven years since the end of the recession, unprecedentedly placing design at the center of U.S. business. We evaluate whether the U.S. education system is currently equipping its young people with designer-entrepreneur skill-sets. In the second section, we describe a traditional academic business incubator model contrasting it with the networked model of Parsons' ELab, making a case for ELab's relevance in helping to develop design-entrepreneurs for the early 21 st Century business landscape.

Defining characteristics of the post-recession U.S. business landscape

The sharing economy

In much business literature, the term "urbanization/agglomeration" describes a phenomenon in which densely populated urban areas generate, nurture, and develop start-up firms. Studies of the relationship between 
entrepreneurship and physical location have focused on i. demand for and supply of entrepreneurship (Rotefoss and Kolvereid, 2005 on Keeble and Walker, 1994 and Reynolds, 1994) and ii. regional demand for entrepreneurship (Rotefoss and Kolvereid, 2005 on Keeble and Walker, 1994 and on Reynolds, 1994). Guesnier (1994). Highly concentrated urban areas provide "start-up insurance" for entrepreneurs, those starting new firms are "virtually guaranteed a qualified workforce, suppliers, clients, services from firms, access to networks of physical and informational infrastructures, and the required risk-capital" (Guesnier, 1994). Access to the accrued and concentrated capital and human resources available in large cities continues to benefit today's entrepreneurs, but these assets do not come cheap. Physical space is at a premium in most of the U.S. urban centers that are attracting startups, and the laws of supply and demand dictate that urban work spaces are a costly investment for firms, as are housing costs (which a firm must factor into their employee compensation costs). This reality is evidenced by an explosive rise in the prices of real estate in Brooklyn, New York, the San Francisco Bay area, and in cities such as Cambridge, Massachusetts and Seattle, Washington. In many of these centers, a speculative anticipated future value is priced into existing property which is often fueled by similarly speculative valuations placed on companies establishing themselves in these locales. Because designers tend to view a constraint as an opportunity, the space crunch in certain urban centers has led to the development of shared workspaces (called co-working spaces), incubators and accelerators. The practical necessity of sharing [scarce] resources has been incorporated into the business models of many recent start-up firms, becoming both the founding concept, and revenue engine for companies such as Airbnb (founded 2008) and Uber (founded 2009), while also embodying a larger ethos with its evangelists and lobbyists. These businesses, which have extended sharing beyond the workspace into (potentially) everything we own, are part of a new movement called the "sharing economy." In the post-2008-recession a new socio-economic system began to gain traction, one that builds upon several natural inclinations that occur when there is scarcity: sharing, bartering, and black market deals that cut out middlemen, governments, tax collectors, and others to cut costs and streamline processes. Further, because of the hardship people experienced -some for the first time in a generation- more empathy and personal enterprise developed; people started caring about sharing. The sharing of knowledge and data on the web proved both practical and cost effective when transferred to objects, property, and skills; the enabling role of information technology:

Reduced transaction costs and made sharing assets cheaper and easier than ever -and therefore possible on a much larger scale. The single biggest change was the availability of more data about people and things, which allows physical assets to be disaggregated and consumed as services. ("The Rise of the Sharing Economy", 2013)

Once complete strangers began sharing what they owned, and bartering their services over the internet on sites such as Craigslist, technology startups emerged behind them and these leveraged the internet's ability to reach and connect millions of people at relatively little cost. The internet's utility and low cost synergized with this new cultural and philosophical openness, born of both a necessity and a willingness to share (particularly amongst the internet generation, roughly those born between 1980-2000). The current recognizable face of this trend are companies such as Airbnb, TaskRabbit, Uber, and Lyft; many of these firms now command enormous valuations by acting as middlemen for traditional services such as transportation, labor and accommodation. The firms who have successfully combined this sharing ethos -enabled-by-technology- have posed a considerable competitive threat to traditional businesses that had become too exclusive, expensive, inconvenient, and out of touch with their customers or users (e.g., Airbnb at time of writing is much larger by volume and market cap than any of the 
world's hotel chains). The sharing paradigm has created tremendous opportunities for businesses to experiment with different approaches to their suppliers and supply chain in creating shared value through common interest versus competitiveness and mistrust [based on] past ways of doing business. A recent study by AMA Research shows that supply chain collaboration can add as much as three percentage points to profit margins for all types of supply chain players. Wal-Mart has experienced significant success in this regard. Using a joint initiative with Procter \& Gamble (P\&G) called collaborative forecasting and replenishment (CFAR), managers from both WalMart and $P \& G$ jointly forecast sales of $P \& G$ products at Wal-Mart stores and plan replenishment strategies (Choppa \& Meindl, 2001). This collaborative mindset in consumers and employees has brought pressure to bear on businesses to be more responsive and transparent. The fundamental argument about whether the purpose of a company is to maximize shareholder value or pursue broader social ends, seems to be privileging the latter. In an age in which well over a billion users across the globe regularly use Facebook, and online platforms such as Yelp exist primarily as customer opinion databases and aggregators, brands can no longer turn a deaf ear to consumer opinions, needs, and desires. This realtime sharing of opinion has engendered an interest in customization and a preoccupation with intangible and experiential values leading the "new economy" away from a Fordist emphasis on efficiency through production specialization and toward tightly coordinated and cooperative service-based, digitally-enabled modes of production. Much has been written about movement toward the notion that sharing is more important than owning. This "sharing economy" utilizes a networked, socially-mediated exchange that is, in some ways, similar to the old economy; it is still transactional, economies of scale enhance value, status still counts, and opinion leadership can be crucial. However, it remains functionally distinctive in its processes and intent.

\section{Technological interconnectedness and networked productivity}

Alexander Graham Bell invented the telephone in 1876. In 1915, the first coast-to-coast call made in the United States required five operators along the 3,400 -mile $(5,500 \mathrm{~km})$ route to patch the connection together. The link, from New York to San Francisco, took 23 minutes to establish, and user costs were high. In 1927, fifty-one years after Bell's invention, AT\&T offered calls between the U.S. and London; initial capacity was one call at a time, sound quality was very low, and the cost to the caller was $\$ 75.00$ ( $\$ 1000.00$ in 2016 dollars) for the first three minutes. Clearly, as with every new technology, all three crucial factors of capacity, quality and cost improved relatively quickly. It was not until the 1970 s that networked computer communication protocols and technologies were developed, initially in universities and within federal agencies, and then, from 1973 at Xerox (PARC) and Motorola, for commercial applications. By the 1980s, commercial video conferencing was becoming available, but much like the U.S.-to-England calls of the 1920 s, costs to businesses were high; they ran as much as $\$ 250,000$ for the product with additional line charges of $\$ 1000$ per hour. By 1985 , the internet was a well-established technology. DARTnet made video conferencing history in 1991 by successfully connecting a transcontinental IP network consisting of more than 12 research sites in the U.S. and the U.K. using T1 trunks. It was this platform (VOIP), that introduced the world to free services and software, such as Yahoo Messenger (1998) and MSN Messenger (1999), slightly preceding the advent of widespread, high-speed/low-cost internet in 2003. Skype was founded that same year and began to develop video conferencing; in 2006 Skype introduced "voice conferencing," which includes real-time video. Today, more than 500 million people have Skype accounts [and it has 74 million regular users]. This free internet-based voice, video, and messaging service now accounts for $40 \%$ of all international telephone traffic. Skype, as of June 2015 , claims that $35 \%$ of small businesses use it as their primary communication service. The newer iterations in communication technology have changed society in 
substantial ways. However, it was perhaps only with the advent of mobile phone app-based videoenabled communication tools such as Whatsapp (2009), Apple's Facetime (2010), and Facebook's Messenger (2011) that the ubiquity and choice of free person-to-person and video conferencing options made both entrepreneurs and their employees more acutely aware of how real-time video, voice, and file-sharing (Google docs., 2007) capabilities could profoundly affect their firm's workflows, dramatically improve productivity, and erode, if not entirely replace, the need for physical work space. Today $37 \%$ of America's workforce has telecommuted, up from $30 \%$ in 2005 and $9 \%$ in 1995; this is part of a trend that is expected to accelerate. The overarching principle uniting the sharing economy and communication technology sections, is adoption of "lean strategies": the leveraging of limited resources. The dramatic rise of the very companies responsible for developing lean business communications' digital infrastructures (e.g. Google, Facebook, and Microsoft (Skype's parent company)) is instructive: a firm can achieve outsized valuations through the development and deployment of tools to support the workflow of networked communities. To this end, a host of applications (e.g. Slack, Dropbox, Worldclock, Evernote, Trello and Basecamp) have been developed to support further productivity gains amongst today's distributed workforce.

\section{A purpose-driven generation}

The post-recession view that consumers now hold about the way business should operate is crystallized, in the popular imagination, through artifacts such as the recently released financial-world drama "The Big Short" detailing the short-sighted greed of key actors in the U.S. banking system. The rise of political candidates such as Bernie Sanders (whom millennials support in overwhelming majorities), also provides a popular focal-point for this new mind-set. The view that business need to operate in socially and environmentally responsible ways has been forged in the twin crucibles of the great recession and the implications of global climate change. As a consequence of these forces, consumers now expect, and often demand, that the brands they use reflect their values and/or articulate and espouse their values; millennials place high emphasis on Corporate Social Responsibility (CSR). The new spenders in the economy, millennial consumers expect businesses to manifest responsibility to their communities, both internally and externally: not only with their shareholders, but also with suppliers, employees, and customers. No longer seen as monolithic, companies can now build or destroy social (and therefore actual) capital very easily and quickly. Social trends have likewise affected business, bringing about more robust commitments to corporate, social, and environmental responsibility, not as a choice but as a requirement of doing business. The way we build companies and products has changed, what we desire and how we perceive value has changed. Firms such as Toms (shoes, founded 2006) with it's "one-for-one" program and Warby Parker (eyewear; founded 2010) with it's similar "buy a pair, give a pair" program tell the story of their company's philanthropic point-of-view to the consumer through their respective websites. Supply-chain transparency is an ethical position that many firms now understand has consequences on their financial bottomlines, and many use the web and social media to influence consumer opinion. Fry and Faerm (2015) discuss the intent of Everlane's (apparel; founded 2010) embrace of a 'Radical Transparency' strategy to disclose its investments in improved working conditions and salaries across its production and distribution system locally and internationally, asserting that Everlane's strategy fulfills the social and financial sustainability goals of Elkington's (1997), Triple Bottom Line (TBL) business philosophy. A 2016 Forbes article contends that the company's "itembased vs. collection-based" approach enables them to focus on apparel basics that are made to last -a strategy that also has [positive] environmental consequences - Elkington's third T. 
The national headline unemployment rate, officially $4.9 \%$, currently stands at its lowest since 2008. However, youth unemployment, amongst those aged 20-24, remains stubbornly high, standing at $9.8 \%$ in January 2016 , double that of the overall rate. Young people are looking for quality jobs and many do not find them; meanwhile, businesses seem unable to fill open positions. This "skills gap" in the employment market indicates that students are graduating from American schools without the 21st Century skills and mindset that businesses require. What are 21st Century skills? P21, the Partnership for 21st Century Learning, defines "the 4Cs" of 21st Century skills (in contrast to content knowledge) as "critical thinking and problem solving, communication, collaboration and creativity and innovation" ("What is 21 st Century," n.p.). In today's U.S. economy, a protracted recession has been followed by low growth together with rapid technological change, shortened product lifecycles, global competition, and the need for continuous skills acquisition. As a result, companies are being pressured, and are, in turn, pressuring their employees to be agile and flexible. With the shift toward online work teams and telecommuting over the past 10 years, many businesses have parceled their operations into collaborative networks of smaller organizations along the value chain. This has become known as the "networked economy" (or workplace). Research has shown that technologies have driven a de-emphasis on the role of manual labor while requiring a much greater need for interpersonal skills and adaptability. Essentially this means that there has been a reduction in skills that compete with machines and a corresponding increase in skills that complement machines. In some cases, communication technologies themselves have created opportunities for new complementary skills in domains in which human customers prefer to interact with another human such as in customer service areas of a business. In this regard, firms such as Zappos (founded, 1999) built their advantage -relative to much larger thencompetitors such as Amazon (which has now acquired it)- through the quality of their customer interactions. Workers at the beginning of their careers, or with many years left in the workforce, will need to be agile, expect and embrace constant big changes, and be able to adapt, learn new skills, and find new occupations that complement the new technologies that will arise. Charles Handy describes this as the "new portfolio approach" to professional life in which one thinks of one's career as a series of passions, interests, activities, and skills that underlie a role or title instead of identifying a résumé of past titles that perhaps no longer exist.

\section{The Design-Entrepreneur}

Entrepreneurship and the new mindset

In 2014 it was estimated that $34 \%$ of the US workforce were freelancing, according to a study commissioned by the Freelancers Union and the Elance-oDesk; 14.3 million of the 53 million freelancers counted in the survey were moonlighting. These are people with full-time employment doing independent work on the side; another 5.5 million were temporary workers. This upward trend in freelancing and entrepreneurship has fueled the startup culture in which businesses can be scaled flexibly as needed. This is especially prevalent in the technology sector which has seen the largest increase and growth over the past ten years. An important determinant of entrepreneurial success is individuals' abilities to handle the stress inherent in taking risks; calculated and considered risks, but risks nonetheless. A corollary to risk is the possibility of failure, and compounding this, is the fact that a majority of startups, by necessity, work with lean budgets (rather than financial cushions). This necessitates inventive ways of stretching a dollar in ways that many full-time employees of large companies, and the MBA graduates of the past, neither expected nor were accustomed to. According to Daniel Pink "the future belongs to a different kind of person with a different kind of mind: artists, inventors, storytellers-creative and 
holistic 'right-brain' thinkers whose abilities mark the fault line between who gets ahead and who doesn't" (Pink, 2005).

Pink discusses what he describes as the "conceptual age", the latest epoch, occurring after both the industrial and the information age. He argues that the conceptual age economy is about high touch (understanding the nuances of human behavior and interaction to create delight and joy) and high concept experiences (being able to find synergies and weave narratives together). We summarize here the following six attributes Pink advocates as indicators of professional success and personal fulfillment in the conceptual age economy:

i. Design: Beyond their function, the design of artifacts, services, and systems must account for both aesthetic and human factors

ii. Story: Data are not the only consideration; the narrative behind why something is significant is crucial.

iii. Symphony: In moving from an information age to a conceptual age, we have become more conscious of making sense and synthesizing meaning (connecting the dots).

iv. Empathy: In addition to logical methods, it is necessary to understand people, to relate to them, and understand their positions and situations.

v. Play: It is a scientifically proven fact that there is enormous health, social, and innovation benefits in playfulness, humor, games, and laughter. This needs to be taken into consideration.

vi. Meaning: There is a larger purpose in our lives than material objects and assets that must be accounted for.

As with entrepreneurs, designers are naturally risk takers, and this is part of the designer's iterative process. Designers generally don't view their process as risk-taking but rather as a prototyping and testing of designs or ideas; it is a heuristic method of figuring things out. This is a mode of working that is familiar in the web design and development sector (cyclical iterative processes and methods); see Figure 1 below. These same methods are now being applied to business systems and services; rapid prototyping enables designers to quickly pivot, based on prototype and user test feedback, and actually mitigate risk. As David Kelley of IDEO asserts [one should] "fail early, fail often to succeed sooner." Failing in the lower-stakes early stages of development has become a business mantra. (See Figure 1) As with entrepreneurs, designers usually have well-developed multitasking abilities, tend to be tenacious problem solvers, and are often very good at strategic planning and forecasting. After all, much of business is about timing the market, and one's ability to forecast where it is going is a sought-after skill. Additionally, companies increasingly seek out design thinker-entrepreneurs because of their flexible open mindset, their understanding of lean design methods, strategy and testing-before-launching, as well as their autonomy and initiative. Such employees are frequently tasked with developing new sub-brands or line extensions, or to chart out future visioning for their brands. These individuals are often called "intrapreneurs" working within the company but are afforded more freedom than a traditional seniority-based firm would typically have extended. Intrapreneurs essentially manage a division, sub-brand, business, or department in a similar manner as they would a small business of their own. This can be viewed as a relinquishing of control, or a bestowing of autonomy on key employees. Either way, the gambit has paid off for many companies. A notable example is that of Spence Silver, an employee of $3 \mathrm{M}$ and inventor of the Post-It note. "3M has been particularly 
successful at encouraging intrapreneurs" [it maintains that the first thing you have to do is to create a corporate culture which permits ideas to blossom]. "You have to kiss a lot of frogs to find the prince [the company told The Economist] but remember, one prince can pay for a lot of frogs" ("Entrepreneurship", 2009). A recent trend sees employers seeking out and hiring entrepreneurs regardless of their track records. A serial entrepreneur who has failed a few times -as well as succeeded- is considered by many firms to be a valuable asset. The startup mentality and lean methodology had helped to create many innovations we see on the market today, from both start-ups as well as within large firms.

"Design Thinking", and the popular imagination

A methodology promoting a user-centric approach to innovation, coined "design thinking" by IDEO, codified a set of processes widely known to be behind some of the most important businesses within the new economy and made these widely sharable. Companies from Warby Parker and Airbnb to Apple, all have design thinking embedded in their DNA. Apple has been very successful in developing devices and services that anticipate what consumers want. If one company can claim to be a design standard-bearer it is Apple; design and design thinking have helped it to make anticipation of consumer demand and desire an almost routine expectation. Apple's design-driven business model is consistently written about and celebrated in the press and by the entertainment industry; this is evidenced by the recent biopic Steve Jobs. The fact that a corporate CEO is even the subject of a mainstream Hollywood film demonstrates how willing popular culture now is to cast protagonists (such as Jobs) as design leader-heroes. Apple's design-focused narrative includes the meteoric rise of Sir Jonathan Ive, Apple's product design chief, who currently occupies a position of virtually autonomous decision-making since his (2015) promotion to the role of Chief Design Officer (CDO), an emerging title, job description and influential corporate role. A recent New Yorker article asserts that a "business truth [is that] more than ever, Ive is the company" (Parker, 2015, n.p.). Indra Nooyi, Pepsico's CEO, credits innovation in her company and a corresponding uptick in sales and stock price to design thinking -highlighting the 2012 hiring of Mauro Porcini- Pepsi's first-ever CDO, as the catalyst for positive change at Pepsi. Design's role in business, therefore, is glamorous and inspiring yet at the same time, deeply pragmatic: profoundly affecting many firms' fiscal bottom-lines. In 2012, Apple set a world record for fastest market capitalization growth, overtaking corporations like Exxon-Mobil, GE, Microsoft, and IBM, soaring to number 1 from number 85 (in 2007) on the Financial Times Global 500 List. This story is part of a larger trend in which design leaders such as Apple and Google displace more traditional businesses (banking and energy particularly) in global rankings of companies by market capitalization. The two tables below compare pre with-post-recession rankings, demonstrating the ascendancy of so-called "tech" companies (shown in bold type), we define these as firms in which technology and designenabled innovation is central. (See Table 1 and Table 2) The larger story lies between the two tables above, in the intervening eight years from the beginning of the great recession to the present, when we examine FT's top 100 companies. In 2007, banks accounted for 23 companies globally -oil and gas producers for 13- while software and hardware accounted for 6 . By 2015 , banks accounted for just 6 -oil and gas producers for 5- while software and hardware had doubled to 12 companies globally. Although in 2015, no post-recession sharing economy companies were represented in the FT 500 list, Uber and Airbnb (for example) grew more rapidly than incumbent competitors in their respective sectors, and may be represented in 2016's list. (Note: neither company is currently listed publicly).

The design-entrepreneur as business leader 
In the recent past, designers were viewed as the "creatives" in an organization; they were quarantined from the decision-making functions and consigned to developing the concepts, products, prototypes, pitches, look, feel, and/or function of a product or a brand. When the "C suite" needed to talk about business -designers were asked to leave the conference room. In contrast, today's designers (Jonathan Ive is a case in point) often lead the room; as a process and method- design is used in all parts of consumer's lives. Design, therefore, has permeated all facets of business today. In the business context, design no longer has edges or boundaries -it infuses all parts of today's more innovative businesses-and, in education, we note a rise in the phenomenon of design schools teaching business and business schools teaching design. Given the broadly-acknowledged status that designers can now command in many firms, what opportunities exist for the professionally trained designer in the future creation of value in business? Moreover, can creativity in business (epitomized by Apple's imperative to "Think Different"), actually be taught? The designer's role has undoubtedly expanded; while there is still need for the fashion designer, the architect, the graphic designer, interior designer, and product designer -we now add to these traditionally-understood professions, newer forms of design such as (e.g., strategic design and systems design, user experience (UX) design, and user-centered design or human-centered design). The proliferation of design's new sub-disciplines mimics the changed business environment. In the design field the traditional (codified) disciplines evolved -while still remaining recognizable and distinct from each other- for more than a century. The newer disciplines are only at the beginning of their adoption into tertiary design education and the implications of this promise to be profound; design is beginning to be thought of as an essential part of the development of a mind, and, skillset needed for innovation in a corporate culture in which $47 \%$ of American executives say their plans for growth are being hampered by lack of access to the right leaders (Oxford Economics, 2014). Ezio Manzini's book, Design, When Everybody Designs (2015), examines social innovation and civic design; important movements occurring now, in which user-centered designers and local communities are using designer's tools and processes to reimagine their own futures. These designers view business, and also government, as new frontiers for innovation and disruption. Roger Martin has called this the "Design Economy," the successor to the information economy, and, before it, the service and manufacturing economies. Martin argues that this newest shift has profound implications for every business leader and manager: "Business people don't just need to understand designers better -they need to become designers" (Breen, 2005, n.p.). "Big data" -the ability to gather, store, parse, and aggregate very large datasets to derive new insights- is a recent information technology-driven phenomenon. So too is the "internet of things." We have gathered $90 \%$ of all data in the entire world in the last two years and how we are going to put that data to use is speculative, at best, for now. The internet of things enables machines to talk to each other and to share data, thereby becoming "smarter," predictive, perhaps, as Al theorists speculate, even capable of developing a conscience. Do these transformations challenge the role and relevance of the academic institution? How academia is perceived, and how it functions in preparing young people for prosperity tomorrow is currently hanging in the balance as the "return on investment" that higher education represents is being publically questioned both by high tuition costs and designdriven disrupters of traditional business models such as The Thiel Fellowship and Minerva Institute as well as Massive Open Online Courses (MOOCs). The start-up private K-8 school network AltSchool consciously embeds IT-enabled and data-driven pedagogy, using methods familiar to any other business start-ups (such as hackathons and iterative design processes) to evolve new tools and approaches. Although art and design schools have an opportunity to capitalize on the approaches and needs of the new economy, to what degree can urgent questions be addressed in academies which are saddled with many of the same outmoded and antiquated features as traditional businesses (e.g. taxi services and hotel chains)? After all these are the very businesses now being exposed to the disruptive winds of technology-enabled sharing. 
The forces of disruption extend to the entity of the design firm, which was traditionally defined by one or two areas of disciplinary expertise. Increasingly, traditional shops are being replaced by design firms who view design as a 360-degree experience -enabling production from concept to construction- infused into every facet of the business, from soup-to-nuts (without a clear end-point). These firms design daily operations and develop the visioning or planning strategies of their clients. Many of these newer firms are being absorbed into larger corporations but given autonomy (e.g., Fjord was acquired by Accenture in 2013, Adaptive Path by Capital One in 2014, with Capgemini set to acquire Fahrenheit 212 in 2016). Some have seen this trend as signaling the end of the traditional design firm as we have known it. However, many traditional shops are becoming part of networks, facilitated by online collaborative tools which come together with other agents, as needed, to co-create solutions over time in long-standing partnerships, not only as subcontractors but as collaborators, investors, and venture partners. Such firms are seen as integral yet independent players, either as a small independent firm or freelance enterprise.

\section{Education and America's New Business Landscape}

Educating entrepreneurs in -and for- America's new businesses.

Between 2008-09 the United States experienced its largest recession since the Great Depression of 1929-39; this recession has had a domino effect on the global economy that is still felt seven years later. The rapidly escalating pace of growth from 2000 to 2008, followed by abrupt subsequent slowdowns and shifts in the economy led policymakers, journalists, and educators to identify gaps in the skills that the U.S. population was acquiring at school and in the workforce. A new scrutiny was given to education - from elementary school curricula to graduate-level programs at universities- with the overall mandate that the education sector must help to create graduates who can adapt rapidly to new circumstances and opportunities. Politicians frequently state that change is needed, within our education system, in order to prepare students for the workplace of the 21 st Century, however excessive focus on the pros and cons of standardized testing and the debates over the Common Core curriculum have led many experts to overlook the importance of being highly adaptable. Adaptability and developing, in students, an ability to create change are skills which need to be taught. Changemaking is a fundamental and integral part of the process of design -in this spirit, in the early 2000's, some design-pioneers re-imagined the education system in an attempt to predict where economic development, and the skills and innovations needed to support it, were heading. In 2003, Roger Martin, (at that time Dean of the Rotman School of Management at the University of Toronto, Ontario) partnered with the Ontario College of Art and Design to offer a series of courses collaboratively. In 2006, the Illinois Institute of Technology's (IIT) Institute of Design launched a nine-month executive master's program in Design Methods. In 2004, at Parsons School of Design, a BBA program in Design and Management was reimagined as a design thinking-business hybrid. In 2005, Stanford University launched their "D-School" facilitated by professor David Kelley, also founder, chairman, and managing partner of the design firm IDEO. Kelley is quoted as declaring that, "we want to produce T-shaped thinkers" (Fast Company, 2005). This concept was first described in an article by David Guest "[as] combining analytical thinking -the vertical leg of the T- with horizontal thinking: intuitive, experiential, and empathetic". In 2008 California College of Art (CAA) launched its MBA in Design Strategy, and that same year New York's School of the Visual Arts (SVA) launched their MFA in Design for Social Innovation program. Most recently, in 2012, Parsons launched its graduate MS program in Strategic Design and Management with a curriculum based around design thinking as business methodology. In Europe similar curricula realignments and conflations have 
occurred; the infusion of design into business curricula has had a profound impact. The UK Design Commission's Report from 2011 recognizes that:

Design skill-sets provide an extra visual language and a logical structure and framework for critical and creative thinking. Design also encourages behaviors which unlock practical competence in non-academic students to help them develop resourceful optimism, motivation and a sense of agency. (UK Design Commission's Report, 2011).

In a 2013 article presented at the 2nd International Conference for Design Education research in Oslo for Cumulus (an association of design academics), Wright, Davis, and Bucolo stated that "education systems must concentrate less on specialist skills and more on the development of adaptable people with broad-based problem solving skills, diversity of perspective, and social and interpersonal communication skills necessary for networking and communication" (Wright, Davis, \& Bucolo, 2013). The relationship between design education and adaptability is also recognized by the Partnership for 21st Century Skills (2009) who champion "preparing students, workers and citizens to thrive in the global skills race to ensure economic competitiveness involves a focus on innovation, creativity, critical thinking, problem-solving, communication and collaboration" ("What is 21st Century", 2009). In the Asia-Pacific region (Australia, New Zealand, Singapore, Hong Kong, Korea) design is being acknowledged by -and infused into- primary and secondary schools. In Singapore, children are exposed to design education programs in both primary and secondary schools, and 'Design and Technology' is a compulsory subject in lower secondary schools. In Australia and New Zealand high-school students are now given opportunities to enter design-innovation-entrepreneurship competitions (e.g., University of Newcastle's 2015, Year 11 [high school Junior-level] "Business Plan Challenge" with its tagline that "your idea can change the world"). As with entrepreneurs, successful designers must identify opportunities and observe and study phenomena to validate hunches, question existing assumptions and practices, frame and envision a better future, to work heuristically (through trial and error), and be willing to fail and to reinvent. It is therefore not surprising to note that AirBNB's founder and CEO, Brian Chesky, a graduate of Rhode Island School of Design (RISD), declares that "everything we do is design-driven." A 2010 IBM survey found that the most successful organizations co-create products and services with customers, integrate customers into their core processes and that businesses are adopting new channels to engage and stay in tune with their customers. By drawing insight from the available data, IBM found that successful CEOs make customer intimacy their highest priority. A design education can offer students the skills that today's business leaders seek in organizations seeking to create value for their customers; these skills include collaboration, empathy, practical problem solving, social responsibility, multidisciplinary approaches, inventive use of technologies, adaptability, and design thinking. Today's designinflected leader draws on the needs of people, and combines these with the opportunities technology affords synergistically within available parameters for business growth. Design's iterative approach makes it more resilient to the changes in economic climate or rapid changes in technological advancements. On the governmental level we see a similar acknowledgment with regards to the needs of citizens and society; in a recent National Governors Association report, the role that arts, culture, and design play at the state level are perceived as driving economic growth and invigorating economic expansion. Governors and states are discovering that arts, culture, and design can be important components of a comprehensive strategy for growth; they touch the economy at crucial leverage points, including innovation, entrepreneurship, employment, and revitalization. An arts, culture, and design strategy, coupled with other strategies, can provide states a competitive advantage. President Obama's 2015 budget requested $\$ 2.56$ billion dollars for investments that promote innovation and collaboration among secondary and postsecondary education and business and industry 
so that students gain the knowledge and skills they need to be successful in today's economy. However, there is still an insufficient adoption of design in either the workplace or in education, a force that may help to counter the (still high) rate of youth unemployment in the United States. Having argued for the necessity of a design education that recasts design as an entrepreneurial activity with deeply practical implications for every facet of business, we turn to how this might be taught. Uncertainty is... uncertain, and design schools - perceiving the shifting design-business landscape, and confronted with the rapidity of change and the multiple permutations of the design-business nexus- are in the process of considering how to respond to this uncertainty. In the following section we discuss the American business incubator, the phenomenon of business incubators in academic institutions and we analyze the Parsons' E-Lab, a design school-based business incubator that we believe helps prepare students for the complexities of today's design-business landscape. Incubators seek to turn academic innovation into actionable and monetizable businesses, support new ideas through entrepreneurship, generate income and foster economic growth within a region. The number of incubators is rapidly growing worldwide; most recently in emerging market economies. New data from the National Business Incubation Association show that about one-third of the 1,250 business incubators in the United States are located within universities.

\section{Entrepreneurship and the american academic incubator}

Academic incubators housed on campuses have long been associated with engineering, medical, and business schools within universities. These are viewed as domains within which university research can synergize with business planning to create start-up businesses based around the research innovations. For their part, universities can gain valuable intellectual property (through licensing agreements). These arrangements earn income and sometimes create revenue streams for the institution should the business become commercially viable; additionally, a lively incubator culture draws top student and faculty researchers to a university. Neither a classroom nor a study center -these incubators are intended to be places where student and faculty researchers and alum are introduced to business, or places to matched with collaborators and mentors through faculty or alumni connections. Academic incubators are usually funded by the parent university often with endowment money; they report directly to its leadership and, most importantly, are embedded in the broader agenda of the university. As a result, the structure and culture of such incubators are often heavily influenced by the university's culture -and the priorities of the academic world- rather than the professional one. Sometimes though incubators serve as agents of change in the university; they can shape and influence the way academic programs, curricula and research projects are envisioned and structured. This new generation of innovation units thus take an instrumental role in redefining the economic and social environments in which the university operates. A traditional academic incubator is usually managed by a small team and led by a faculty member who is also part of the academic program. A survey of available literature dealing with the success of academic incubators shows that the key factors that enable success in such a setting are: infrastructure, network, university reputation, and human and technical support. Academic incubators are campus-based and offer consulting and advising resources (advisors, mentors, and faculty expertise), infrastructure resources provided by the university (working space, innovation hub/center, technical support), and financial resources (university venture capital, monetary prizes for selected competition winners, competition for stipends covering up to the students' loan balances, and an increased use of crowd funding methods).

Traditional mentorship: one mentor, one entrepreneur 
In an effort to support students in their ventures, some academic incubators provide mentorship programs. These programs provide much needed guidance to students on how to build successful companies, and provide a channel to promote knowledge and experience transfer. Mentors are usually assigned mentees based on their expertise or the mentees' preference. In addition, mentors participating in these programs are often entrepreneurs in addition to being faculty members. The mentors share their knowledge during regularly scheduled meetings with their assigned mentees, where they help their businesses not only get off the ground but also establish a sustainable model in which to operate. Mentors also share their experience through talks, presentations, and workshops with members of the university community. (See Figure 2)

Traditional ways of measuring value: are KPIs enough?

In academic incubators, measuring value is still considered a nascent phenomenon and many academic institutions are not currently tracking the success of their incubators, nor measuring the "value-add" within their own ecosystem. For the few incubators that actually define success metrics and track these, such efforts are usually limited to tracking the amount of funding attracted by businesses and sponsors. From the faculty side, success in attracting funds is a key criterion for promotion. In an HBR article, Sramata Mitra (2013) discusses the problems faced by incubators, and discusses potential solutions. Mitra emphasizes that in order for incubators to achieve success, they need to add value and measure success beyond only the financial metrics. With an increase in the number of academic incubators, there is a corresponding increase in the number of fields covered, and, as previously noted the new entrepreneur now tilts toward more socially-oriented and impactfocused values. In response to these factors, the academic community needs to reconsider the meaning of success; what are the criteria for gauging success; what are the relevant metrics to track and measure it; what kind of impact and values should an incubator promote? Can academic incubators develop both common and differentiated metrics for tracking success -in conventional business ventures and also in social innovation businesses? Companies such as UBI Global are providing regional and global academic ranking by tracking common performance indicators such as number of jobs created, taking into consideration variables, non-similar ecosystems, and Key Performance Indicator metrics (KPIs). While such companies provide differentiated benchmarks for social innovation incubators, we assert that existing ways of measuring incubator impact must be measured against the needs of the new economy. Our proposed new economy-inflected expansion of measurement criteria includes criteria such as learning-from-failing, and ability to adapt and pivot in response to a rapidly changing landscape, amongst others; skills we've determined are necessary in navigating the demands of the new economy. A criterion such as learning-from-failing present challenges for any organization -incubators being no exception- particularly as its implications and impacts are long-term.

The vision gap: limitations of the traditional academic incubator

According to The Young Entrepreneurs Council, three quarters of business school students do not have access to academic entrepreneurial resources. In addition, in an article published in December 2015 in the New York Times, the following aspects were identified as lacking, and in need of improvement, in order to enhance the entrepreneurial experience:

- Interdisciplinary collaboration - Focusing on business sustainability - Hands-on, experiential programs 
Despite their high potential and considerable success as a driving force for innovation within universities and surrounding communities -academic incubators- like businesses, can easily be mismanaged in ways that lead to irreversible setbacks. According to the American Council on Education's Center for Education Attainment and Innovation's 2015 research report, the innovation unit (academic incubator) should be transparent with regards to its mandate, activities, objectives, and, results. Such units should integrate into the academic setting from which it stems, embrace its culture, and leverage its research and groundbreaking work. Finally, academic innovation incubators succeed when universities are able to put all required resources at their disposal, including infrastructure, mentoring, financial resources, and technical support. Such endeavors require a substantial amount of logistical capacity, planning, and collaboration. It is therefore imperative for the academic incubator's managing team to clearly state their objectives, practice transparency, and leverage all the university has to offer by fostering collaboration and openness. What happens when an academic institution can not meet these goals; is limited by the economic constraints of the new economy; is limited by the high cost of real estate in urban campuses - or the institution has an incubator, but it is housed on campus with limited physical space and unable to scale to meet increased demand? Can the dynamics (or key factors) that have helped define the strategies of many postrecession U.S. startups (i. the sharing economy, ii. technological interconnectedness, iii. adoption of purpose-driven or cause-related value proposition(s) and iv. adaptability in the face of limited resources) be part of a strategy for academic institutions, such as art and design schools? Schools lacking the deep pockets that many 'Research 1' universities in the U.S. have at their disposal to support their students?

A case study: the Parsons Entrepreneurial Lab

Design-driven, networked model

The Parsons Entrepreneur's Lab (ELab) is a design-led business lab that is dedicated to the research and practice of design-led entrepreneurship. It offers programming for current students, recent graduates, and longterm alumni through partnerships, collaborations, grants, and (soon to be) crowd-funding. ELab is a prototype or model of today's distributed workplace with its lean operating budgets, lack of a specific physical locale (ELab does not have a physical space but it is housed, conceptually, within The New School), and distributed (rather than centralized) model -embedding its fellows within co-working spaces or incubators in the greater NYC startup community- it is therefore easily scalable. In contrast to the traditional academic incubators we have described (to which the term "ivory tower" may accurately be applied; refer to Figure 2), ELab is distinguished by Parsons' design thinking methodologies and the progressive roots of The New School. ELab has social entrepreneurship, sustainability, and TBL (Triple Bottom Line) values and principles embedded in its DNA. It aims to support and strengthen student evolution from academic-to-applied practice through extra-curricular programming, workshops, and mentorship in a variety of practical business and lean design processes to enable them to develop a minimum viable product and gain traction, preparing their new ventures to compete and thrive in the post-recession landscape. Within the nation's design school community, currently only Pratt Institute has an incubator, and Pratt is not currently testing a distributed (networked) model that builds upon sharing-economy concepts. The networked model is a system where value is co-created and exchanged, in a distributed way, through a network of participants. Components of ELab's networked model are based on the following components:

- Existing networked business models A company's value-producing assets are connected to each other and with other organizations with one of more common objectives. 
- Value exchange networks An interconnected exchange of business assets with other organizations. Collaborative consumption and the sharing economy Peer-to-peer sharing of access to goods and services. P2P services (peer-to-peer) Processes that aim to increase the most widespread participation by equipotential participants. - Bottom-up values exchange The idea that each individual is considered on its own as well as within the context of the lab and the greater community or landscape. - User-generated content Participants in the lab generate content for the lab, its blog or website as well as assisting in the development of the research conducted by the lab. - Design processes of problem solving, iteration and lean prototyping Through our programming we assist the startups to use Parsons design processes for innovation. - Scalable Business model: Since the ELab model is not restricted by any physical location, the potential of scalability is more easily attained. Because of the business model, it is an inexpensive way to support future entrepreneurs, offer progressive educational opportunities, hands on learning and skills to meet the demands of tomorrow's workplace.

A considerable part of ELab's design ethos emphasizes sharing, testing, learning, and launching; therefore, ELab fellows are encouraged to work together to share information, skills, and insights that might be helpful to one another. Some members barter services such as user experience design or graphic design, while others share relevant information at meet-ups, or through email. The ELab's website has a private area within which fellows and administrators can share useful resources that will support fellows with their ventures. In the spirit of the sharing economy and crowdsourcing, ELab is currently organizing a design jam and hackathon event -aiming to attract passionate people with various expertise to collaborate on answering fellows' immediate needs, (i.e., if one of a startup's immediate needs is to create a website, the lab will invite web designers, web developers, and fellows sharing their skills and passion for a couple of hours). At the end of the hackathon, the startup will have a functional new website to further develop, and will be able to move to the next level. ELab also collaborates with other incubators (Google's "30 Weeks") and opens its events to selected external fellows. It also participates in networking events that enable fellows to meet potential collaborators or service providers, learn more about what other entrepreneurs are working on, and exchange resources and skill-sets. Additionally, ELab fellows give back a few hours per month to help run the lab and support the research and outreach (e.g., the graphics in Figs 3-5 in this paper were partially created by a fellow, under the give-back condition). This sharing builds a sense of community and bottomup innovation around the program, and a focus on immediate needs. Students, faculty, and part-time lecturers (who are working professionals) run the lab; this creates a lean organization that requires little financial commitment from an already overtaxed university infrastructure. Selected current ELab programs include "Innovate NYC": A collaboration with a consortium of ten New York City based universities (Columbia, Cooper Union, NYU, CUNY, Brooklyn Law, and more), the "Do School", and "NYC EDC" (New York City Economic Development Corporation). This network brings current students from across these universities together to collaborate using design thinking for social innovation. A twelve-month early startup incubator program and a three-month summer accelerator program for recent alumni embeds fellows in greater NYC's sector-specific communities. Fellows gain membership and share their resources, both in terms of goods and service providers, while also leveraging their knowledge and connections to potential partners. ELab emphasizes the importance of fellows' interaction with professionals, companies, entrepreneurs, and the startup community at large. Such interactions are constant, and an integral part of the daily endeavor of building and creating innovation. These partners, four external sector specific co-working spaces (Centre for Social Innovation, Civic Hall, LMHQ and NY Design Incubator), have provided membership and "hot seats" at the heart of their effervescent community, adding clear extrinsic value. Centre for Social Innovation is a non-profit community space dedicated to social entrepreneurship and social justice, with partnerships including Ashoka and Be Social 
Change; it attracts a wide group of passionate, purpose-driven members with locations in Toronto and New York City. Civic Hall is another community center and membership model non-profit space, backed by Microsoft and Google's foundations, and focused on the civic innovation and technology sectors; this also attract social entrepreneurs, change-makers, government employees, hackers, academics, journalists, and artists to share knowledge and build tools to solve problems together. Lower Manhattan Headquarters (LMHQ) created by Downtown Alliance, provides "third space" locations (between home and office) for innovation and technology startups looking to make change in the world; this is backed by business sponsors and foundations. Finally, NY Designs, both an incubator and a 5,000 square foot fabrication space, is an economic development program at the City University of New York (CUNY) in Long Island City, Queens. All these communities offer dynamic environments, networking opportunities, programming, hot seats, and office space. These partnerships, coupled with a wide international network (amongst professionally-situated alumni in NYC), gives the ELab business model advantages that make it easily replicable and scalable in a large city such as New York. Throughout the incubation program -and a few years out- the research team will be surveying their fellows to make sure they focus on immediate needs for their startup's launch. ELab connects experts from the greater NYC community and Parsons' alumni network to advise fellows through mentorship along with various talks, panels, pitch nights, design jams, and hackathons. In order to exhibit fellows' work -and raise awareness while giving them critical feedback- ELab provides three pitch nights as part of the fellowship. This gives fellows the opportunity to pitch in front of a large jury of experts, investors, and the public reaching a larger community, but also getting immediate feedback on their venture. In addition to these offerings, ELab offers legal advice through a partnership with Brooklyn Law's Blip Clinic and Cardozo Law School's Clinic; ELab also hosts design jam events and legal and tax workshops. Another program ELab has developed is the mentorship program; which engages long-term alum and professionals from Parsons' networks, offering them a way of staying connected and give back. Finally, ELab also runs a research program that focuses on the future of entrepreneurship. ELab's research team belongs to a consortium (or network) of incubators and accelerators who meet regularly to openly discuss curricula, business models, marketing, and membership, exploring mutually beneficial methods of collaboration that drive positive impact for budding entrepreneurs. Parsons' ELab incubator model is described visually in Figure 3. Somewhat counterintuitively -for an incubator- fellows are not surrounded by nurturing resources; rather they become a node within a distributed and mutually-nourishing system. (See Figure 3)

\section{Parsons' design methodology and ELab}

Parsons School of Design was recently rated the number one design school in the U.S. and number two worldwide by Quacquarelli Symonds (QS), a UK-based organization that evaluates and rates a variety of established international professional programs, from Medicine to Law; in the latest poll it is ranked third. Regardless of the accuracy of these rankings, the fact that design is now joining other university professional schools' disciplines in credible specialized international rankings is a further validation that design is now taken seriously as an impactful social and economic force. We often describe Parsons' processes -across its programs in the School of Design Strategies- as embodying "design intelligence;" a fusion of business logic, economic, and organizational reality with the important capabilities of design thinking methodologies and human factors. We assert that this methodology will result in practices leading to superior business results, enhanced sustainability, and greater social value. We add to these methods lean strategy (including prototyping) which helps entrepreneurs to create feedback loops that facilitate rapid iterative development. As an entrepreneur's lab that practices design intelligence and lean strategy-for-business innovation, ELab is a natural extension of Parsons' 
existing programs. ELab and more traditional university business incubators both leverage and synergize the curriculum-incubator relationship, however the key point of differentiation between these incubators and ELab is the latter's practice of design processes, design thinking, lean strategy, and distributed workflows as integral, applied processes. "Social entrepreneurship" is the attempt to use business techniques to solve social problems. It has been a core pedagogical principle at Parsons and the New School for over a decade and it exists also in the DNA of ELab. The startups curated by ELab seek to address social problems on a large scale, becoming change agents in society, seeking to improve systems, reinvent experiences, and transform approaches to ingrained societal problems in innovative ways.

\section{Parsons' Entrepreneurs Lab strategy and offerings}

ELab has created a six-point strategy plan (see Figure 4). It is intended to target all the stakeholders within Parsons' entrepreneurial ecosystem at all the stages in the growth of an entrepreneur. With this strategy, ELab aims to: build awareness and promote entrepreneurship within the community; support entrepreneurs and help them thrive through creation of a solid program structure and network; engage experienced entrepreneurs to cocreate a collaborative environment and, support startups sustainably in a self-sustaining ecosystem around entrepreneurship and innovation. (See Figure 4)

Mentorship 2:0: leveraging the power of the network

Mentorship programs are an important part of ELab. These programs are targeted toward professionally established alumni and professional experts willing to give back to Parsons and to nurture the next generation of design entrepreneurs, as well as those who may see personal benefit and professional gratification in working with young startups. Currently there are two ways of supporting ELab fellows: in the twelve-month incubator and in the three-month accelerator programs. The first program is the one-on-one twelve-month mentorship in which fellows are paired with a startup through regularly meetings over the course of the year with a focus on helping fellows reach their KPIs and benchmarks. The second is the time-bank to which experts can donate an hour's time for meetings, as needed, with fellows.

The time bank is an opportunity for those wanting to be involved and share their wealth of knowledge and expertise but who may not have ability to dedicate regular monthly time, Figure 5 (below) shows how the time bank functions. Mentors use an online signup platform for fellows to reach out as needed. (See Figure 5)

Measuring success: new metrics for a new economy

The goal of the ELab as a research project is to develop new methods of evaluating success entrepreneurs and their startups for five years (and potentially beyond) to find out the impact that participating in this type of extracurricular immersive, collaborative, design practice programming may have on their communities in regard to job creation and economic impact. It is also to evaluate entrepreneur's choice of career -regardless of whether the startup ultimately succeeds. Measuring failure (and its many lessons) is, likewise, equally important. In our research we are creating feedback loops, benchmarks assessments, and KPI assessments to see if learning certain behaviors and iterative methods coupled with pragmatic skills can be used to condition people's reactions and nudge them towards better, more desirable strategies and actions. As people receive realtime contextual information about their approach, they can calibrate their behavior and make a choice about their next course(s) 
of action. These feedback loops begin with data capture when a certain action or behavior is recorded. This is followed by contextual data sharing -during which processed data is delivered to the user in a way that triggers a need for action. These data can be accompanied by suggestions of various potential actions to take. The final step is action -the subject has processed the data, assessed its relevance, and-and then makes a choice informed by the options presented. Such action is once again captured, to trigger another feedback loop. ELab practices the methods it teaches - using feedback loops to itself improve the value it brings and share findings with the community and it's stakeholders. Ultimately, ELab aims to apply this design research throughout the program timeframe, and for at least five years out, using tools to track qualitative and quantitative data, and focusing on data visualization and other effective forms of communication, of it's findings, to stakeholders.

\section{Conclusion}

In November 2008, close to the great recession's peak, Rahm Emanuel, then President Obama's Chief of Staff, was quoted as telling a Wall Street Journal conference of top corporate executives that "you never want a serious crisis to go to waste". In this statement, he was paraphrasing Britain's wartime Prime Minister Winston Churchill. The crisis of 2008's great recession did not create the dynamics of the new economy (sharing, technological interconnectedness, purpose-driven value, and adaptability). However, the recession's credit shocks -coupled with widespread loss of public confidence in the financial system and scarcity of resources- conspired to catalyze the transformation of the four key dynamics (i. the emergence of the sharing economy, ii. technological interconnectedness, iii. adoption of purpose-driven or cause-related value proposition(s) and iv. adaptability in the face of limited resources) into intentional and valid business strategies. This resulted in a seismic shift in the ways that businesses sought to create value, redrawing the lines of what value actually means for consumers and participants. The implications of how profound this shift has been in many sectors can only be appreciated in retrospect. For example, if we compare a Toms or an AirBNB to their predecessors' business models in the footwear and hotel industries respectively, we see how infused these businesses are with the four key defining factors we define here. Through an examination of the underlying dynamics of how many post-recession (new) businesses create, accrue, and disseminate value -we understand the rise of design and its expansion as a mode of thinking-in-action that is both inevitable and inexorable. Amidst this good news about design's relevance in the world, design education finds itself at a moment of great challenge (as well as great opportunity), and, as with business leaders -design educators risk squandering the opportunity that their own "crisis," (in their case, about the purpose of a design education) affords them- for reconceiving what design is, and does, in a 21st Century economy. Parsons' ELab is currently something of a speculative venture, one that works in a manner distinct from traditional academic incubators in the United States. Cass Sunstein recently stated that "government is problem-oriented rather than theory-oriented" (Tishman lecture, 2016). We argue that design is similarly problem-oriented; the presence of a design-business incubator in a design school possesses great potential in enabling students to heuristically test design and design education's relevance: what design is, and does -in a 21st Century economy- rather than/also in, a classroom. ELab has developed a model in which its fellows must embody, evidence and reflect on post-recession/new economy dynamics of lean strategy, distributed workflow, Triple Bottom Line value creation, and holistic evaluation metrics -and practice them daily. Its success will ultimately be validated by the degree to which its alum creates new value-through-design in the post-recession economic landscape.

\section{References}


All eyes on the sharing economy. (2013, March 9). The Economist. Retrieved from http:// www.economist.com/news/technology-quarterly/21572914-collaborative-consumptiontechnology-makes-it-easierpeople-rent-items Anatassi, T., \& Booth, T. (2013). Career ready: Alumni helps students transition from backpacks to briefcases. The Communicator Western New England University. Retrieved from http://www1.wne.edu/assets/20/communicator2013_07.pdf At Everlane, Transparency Is The New Black. (2016, January 5). Forbes. Retrieved from http://www.forbes.com/sites/mikeotoole/2016/01/05/at-everlane-transparentis-thenew-black/\#1933950b3127 Attaran, M., \& Attaran, S. (2007, May). Collaborative supply chain management: The most promising practice for building efficient and sustainable supply chains. Business Process Management Journal. 13(3), 390-404.

Bauwens, M. (2005). The political economy of peer production. CTheory. Retrieved from http://journals.uvic.ca/index.php/ctheory/article/view/14464/5306 Breen, B. (2015, April 1). The business of design. Fast Company. Retrieved from http://www. fastcompany.com/55581/business-design Brown, T., \& Wyatt, J. (2010). Design thinking for social innovation. Stanford Social Innovation Review. Retrieved from: http://ssir.org/articles/entry/design_thinking_for_social_innovation Bureau of Labor Statistics. (2015, August 18). Employment and unemployment among youth summary. United States Department of Labor. Retrieved from http://www.bls.gov/ news.release/youth.nr0.htmhttp://www.fastcompany.com/3046989/what-millennialemployeesreally-want Buchman, M. L. (2012). Creativity and prosperity in the new economy: Why industry needs good design. Issuu. Retrieved from https://issuu.com/artcenteredu/docs/creativity andprosperity_lornebuchman. Buy a pair give a pair. Warby Parker. Retrieved from https://www.warbyparker.com/buya-pair-give-a-pair Collaborative networks are the organization: An innovation in organization design and management. Drucker Society of Austria. Retrieved from http://druckersociety.at/repository/scientific/Shuman.pdf De Jong, A. (2013). Service design for networked business models [PowerPoint slides]. Service Design Network Conference Cardiff. Retrieved from http://www.slideshare.net/ claropartners/claro-sdnc13-networkservicedesign20nov2013d Education Advisory Board. (2015, February 3). Rise of the robots: Workers need new skills for a new economy. Retrieved from https://www.eab.com/daily-briefing/2015/02/03/riseof-the-robots-workers-need-new-skills-for-anew- economyhttps://www.eab.com/dailybriefing/2015/02/03/rise-of-the-robots-workers-need-new-skills-for-anew-economy Elkington J. (1997). Cannibals with forks: The triple bottom line of 21st century business. Oxford: Capstone Publishing Limited. Elliott, L. (2015, October 6). IMF warns of stagnation threat to G7 economies. The Guardian. Retrieved from: http://www.theguardian.com/business/2015/oct/06/imf-warns-stagnation -threat-g7economies Entrepreneurship. (2009, April 27). The Economist. Retrieved from: http://www.economist. com/node/13565718 Erickson, F. (2011, March 14). The Academic Incubator: Ferris First. Retrieved from http:// www.ferris.edu/htmls/administration/president/sparc/meetings/docs/Academic_Incubator.pdf Fairs, M. (2014, January 28). Silicon Valley "didn't think a designer could build a company" says Airbnb co-founder Brian Chesky. Dezeen. Retreived from: http://www.dezeen. com/2014/01/28/silicon-valley-didnt-think-a-designer-could-build-acompanyinterview-airbnb-co-founder-brian-chesky/ Farhan, J., Kamariah, I., \& Nasir, M. (2015). A review of commercialization tools: University incubators and technology parks. International Journal of Economics and Financial Issues, 5(Special Issue), 223-228.

Freeing up the telephone. (2015, Dec 1). The Economist. Retrieved from http://www. economist.com/news/science-and-technology/21679296-long-distance-telephone-callscost-far-too-much-freeingup-telephone Fry, A., \& Faerm, S. (2014). Post-recession consumerism in the U.S.: The influence of cheap and chic consumer products on perceptions of income inequality. Cuaderno, 53, 169-188. FT Global 5002012. 
(2012). Thomson ONE Banker, Thomson Reuters Datastream and individual companies. Retrieved from http://im.ft-static.com/content/images/a81f853eca80-11e1-89f8-

00144feabdc0.pdfhttp://www.artcenter.edu/accd/files/Creativity AndProsperity_lorneBuchman.pdf GE Foundation. (2015). The skills gap and the new economy: Implications for low-income students. Retrieved from http://www.collegefes.org/pdfs/Skills_Gap.pdf.https://www.

huronconsultinggroup.com/Insights/Whitepapers/Education/ /media/3FABF3A6211B 455EB5BBF81C6B0668D9.ashx Goetz, T. (2011, July 19). Harnessing the power of feedback loop. Wired. Retrieved from http://www.wired.com/2011/06/ff_feedbackloop/ Guesnier, B. (1994). Regional variations in new firm formation in France. Regional Studies, 28(4), 347 - 58. Guest, D. (1991, September 17). The hunt is on for the Renaissance man of computing. The Independent. Retrieved from https://www.huronconsultinggroup.com/Insights/ Whitepapers/Education/ /media/3FABF3A6211B455EB5BBF81C6B0668D9.ashx Gündoğdu, M. (2012). Rethinking entrepreneurship, intrapreneurship, and innovation: A multi-concept perspective. Emerging Market Journal, 2, 63. DOI 10.5195/emaj.2012.20http: //emaj.pitt.edu/ojs/index.php/emaj/article/view/20/130 Handy, C. (1991, Feb 1). The Age of Unreason. Harvard Business Review Press. Cambridge: Harvard University. Hawes, L. (2012, February 14). What is networked business? Forbes. Retrived from http:// www.forbes.com/sites/larryhawes/2012/02/14/what-is-networked-business/\#1661 b92f5279https://www.huronconsultinggroup.com/Insights/Whitepapers/Education/ / media/3FABF3A6211B455EB5BBF81C6B0668D9.ashx Huron Education (2015). Academic innovation incubators: Emerging models and strategic considerations for leaders. Retrieved from https://www.huronconsultinggroup.com/ Insights/Whitepapers/Education/ /media/3FABF3A6211B455EB5BBF81C6B0668D9.ashx IDEO. About IDEO. Reteived from https://www.ideo.com/about/ Improving lives. Toms. Retrieved from http://www.toms.com/improving-lives.http://www. fastcompany.com/3046989/what-millennial-employees-reallywant Jones, J. M. (2015, August 19). In US, telecommuting for work climbs to 37\%. Gallup. Retrieved from http://www.gallup.com/poll/184649/telecommuting-work-climbs.aspx) Kapterev, A. (2011, September 20). Presentation Secrets. San Francisco: Wiley Publishing. Kasperkevic, J. (2015, March 6). US unemployment at lowest since 2008 - but young people still can't find work. The Guardian. Retrieved from: http://www.theguardian.com/ business/2015/mar/06/us-economy-booms-youth-unemployment. Keeble, D., \& Walker, S. (1994). New firms, small firms and dead firms: spatial patterns and determinants in the United Kingdom. Regional Studies. 28(4), 411-27.

Kolvereid, L., \& Rotefoss, B. (2005). Aspiring, nascent and fledgling entrepreneurs: An investigation of the business start-up process. University of Illinois at Urbana-Champaign's Academy for Entrepreneurial Leadership Historical Research Reference in Entrepreneurship. Retrieved from http://papers.ssrn.com/sol3/papers.cfm? abstract_id=1508296. Manzini, E. (2015, February). Design, when everybody designs: an introduction to design for social innovation. (R. Coad, Trans.). Cambridge, MA: The MIT Press. Matofska, B. What is the sharing economy? The people who share. Retrieved from http:// www.thepeoplewhoshare.com/blog/what-is-the-sharingeconomy/ Mead, R. (2016, March 7). Learn different: Silicon Valley disrupts education. The New Yorker. Retrieved from http://www.newyorker.com/magazine/2016/03/07/altschools-disrupted -education. Mitra, S. (2013, August 13). The Problems with Incubators, and How to Solve Them. Harvard Business Review. Retrieved from https://hbr.org/2013/08/the-problems-with-incubators-a Myths about millennials. (2015, July 30). The Economist. Retrieved from http://www. economist.com/news/business/21660110-businesses-should-beware- 
dubiousgeneralisations-about-younger-workers-myths-about Parker, I. (2015). The shape of things to come: How an industrial designer became Apple's greatest product. New Yorker. Retrieved from http://www.newyorker.com/magazine/2015/ 02/23/shape-things-come Pappano, L. (2012, July 19). Got the next great idea? The New York Times. Retrieved from http://www.nytimes.com/2012/07/20/education/edlife/campusincubators-areon-the-rise-as-colleges-encourage-student-start-ups.html?_r=0http://www.nytimes. com/2012/07/20/education/edlife/campus-incubators-are-on-the-rise-as-collegesencourage-student-startups.html?_r=0 Pink, D. H. (2006, March 7). A whole new mind: Why right-brainers will rule the future. New York: Riverhead Books. Poswolsky, A. S. (2015, June, 4). What millennial employees really want. Fast Company. Retrieved from http://www.fastcompany.com/3046989/what-millennial-employeesreally-want Reynolds, P. D. (2005, May). Entrepreneurship research innovator, coordinator, and disseminator. Small Business Economics. 24(4), 351-358. Singerdec, N. (2015, December 28). Universities race to nurture start-up founders of the future. The New York Times. Retrieved from http://www.nytimes.com/2015/12/29/ technology/universities-race-tonurture-start-up-founders-of-the-future.html?_r=0 SINTEF. (2013, May 22). Big Data, for better or worse: 90\% of world's data generated over last two years. Science Daily. Retrieved from www.sciencedaily.com/releases/2013/05/ 130522085217.htm The business of business. (2015, March 21). The Economist. Retrieved from http://www. economist.com/news/business/21646742-old-debate-about-whatcompanies-are-hasbeen-revived-business-business The rise of the sharing economy. (2013, March 7). The Economist. Retrieved from http:// www.economist.com/news/leaders/21573104-internet-everything-hire-risesharingeconomy

US Department of Education. Skills for the new economy: Preparing students for college and careers. Retrieved from https://www2.ed.gov/about/overview/budget/budget15/ crosscuttingissues/skillsforneweconomy.pdf Weed, J. (2015, May 11). Airbnb grows to a million rooms, and hotel rivals are quiet, for now. The New York Times. Retrieved fromhttp://www.nytimes.com/2015/05/12/business/ airbnb-grows-to-a-million-rooms-and-hotel-rivalsare-quiet-for-now.html?_r=1 What is 21st Century learning and citizenship all about? P21 Partnership for 21st Century Learning. Retrieved from: http://www.p21.org/storage/documents/citizenship/P21_ Citizenship_Overview.pdf Wright, N., Davis, R., \& Bucolo, S. (2013). The creative citizen: Understanding the value of design education programs in the knowledge economy. In Reitan, Lloyd, Bohemia, Merete Nielsen, Digranes, \& Lutnæs (Eds.) Proceedings of the 2nd International Conference for Design Education Researchers (Volume 4), ABM-media, Oslo, Norway, pp. 2230-2248.

\section{Resumen:}

La "gran recesión" de 2008-09 en los EE.UU. fue un momento decisivo en el desarrollo de la dinámica de los negocios y se constituyó en una instancia muy prometedora tanto para la creación de una nueva generación de compañías americanas como para la revigorización de empresas ya establecidas. Estos son 1. el surgimiento de la economía colaborativa, 2. la interconexión tecnológica, 3. la adopción de propuestas de valor propositivas o relacionadas con una causa y 4 . la adaptabilidad a los recursos limitados. Este artículo analiza el surgimiento del diseño en el escenario de los negocios en la post-recesión de EE.UU.; se describen los atributos que los diseñadores comparten con los empresarios, incluyendo la capacidad de adaptación, el riesgo y la tolerancia al error, la multidisciplinariedad, la creatividad y una mentalidad orientada a la resolución de problemas. Se describen estas nuevas funciones y formas de trabajo combinado con las capacidades y los recursos intelectuales disponibles en la educación superior. En concreto, se presenta a Parson's E Lab: una incubadora negocios de diseño-escuela que busca replicar el ambiente dinámico de aprendizaje en el escenario de los 
negocios en la post-recesión en Estados Unidos, a través de un modelo en red, orientado al diseño y socialmente comprometido, que contempla los cuatro ejes clave de la estrategia empresarial de start-up en el entorno posterior a la recesión.

Palabras clave:

negocios en la post recesión - incubadora de diseño académica - emprendedores en diseño - economía colaborativa - estrategia de ajuste, economía en red.

\section{Resumo:}

A Grande Recessão de 2008-09 nos EUA foi um momento decisivo no desenvolvimento da dinâmica dos negócios se estabeleceu numa instancia promissória tanto para a criação de uma nova geração de companhias americanas como para o relançamento de empresas já estabelecidas. Estes são: 1) O surgimento da economia colaborativa, 2) a interconexão tecnológica, 3) a adopção de propostas de valor propositivas ou relacionadas com uma causa, y 4) a adaptabilidade aos recursos limitados. Este artigo analisa o surgimento do design no cenário dos negócios na pós-recessão de EUA; se descrevem os atributos que os designers compartilham como os empresários, incluindo a capacidade de adaptação, o risco e a tolerância ao erro, a multidisciplinaridad, a criatividade e uma mentalidade orientada à resolução de problemas. Descrevem-se estas novas funções e formas de trabalho combinado com as capacidades e os recursos intelectuais disponíveis na educação superior. Em concreto, se apresenta a Parson's E Lab, uma incubadora de negócios de design-escola que procura replicar o ambiente dinâmico de aprendizagem no cenário dos negócios na pós-recessão nos EUA, através de um modelo em rede, orientado ao design e socialmente comprometido, que contempla os quatro eixos chave da estratégia empresarial de start-up no entorno posterior à recessão

Palavras chave:

negócios na pós - recessão - incubadora de design acadêmica - empreendedores em design - economia colaborativa - estratégia de ajuste - economia em rede

Design-entrepreneurship in the post-recession economy: Parsons ELab, a Design School Incubator fue publicado de la página 175 a página205 en Cuadernos del Centro de Estudios de Diseño y Comunicación № 64 